\title{
Article
}

\section{Development of the "National Asbestos Profile" to Eliminate Asbestos-Related Diseases in 195 Countries}

\author{
Diana Arachi $^{1}\left(\mathbb{D}\right.$, Sugio Furuya ${ }^{2}$, Annette David ${ }^{3} \mathbb{D}^{1}$, Alexander Mangwiro $^{4}$, Odgerel Chimed-Ochir ${ }^{5,1}$, \\ Kenneth Lee ${ }^{6,1}$, Peter Tighe ${ }^{7}$, Jukka Takala ${ }^{8}$ (D), Tim Driscoll ${ }^{9}$ (D) and Ken Takahashi ${ }^{1,10, *}$
}

check for

updates

Citation: Arachi, D.; Furuya, S.; David, A.; Mangwiro, A.;

Chimed-Ochir, O.; Lee, K.; Tighe, P.;

Takala, J.; Driscoll, T.; Takahashi, K.

Development of the "National

Asbestos Profile" to Eliminate

Asbestos-Related Diseases in 195

Countries. Int. J. Environ. Res. Public

Health 2021, 18, 1804. https://

doi.org/10.3390/ijerph18041804

Academic Editor: Paul B. Tchounwou

Received: 18 January 2021

Accepted: 8 February 2021

Published: 12 February 2021

Publisher's Note: MDPI stays neutral with regard to jurisdictional claims in published maps and institutional affiliations.

Copyright: (C) 2021 by the authors Licensee MDPI, Basel, Switzerland. This article is an open access article distributed under the terms and conditions of the Creative Commons Attribution (CC BY) license (https:// creativecommons.org/licenses/by/ $4.0 /)$
Asbestos Diseases Research Institute, Concord, NSW 2139, Australia; diana.arachi@adri.org.au

2 Japan Occupational Safety and Health Research Center, Tokyo 204-0024, Japan; 2009aban@gmail.com Health Partners LLC, Tamuning 96913, Guam; amdavid@guam.net

4 Secretariat of the Basel, Rotterdam and Stockholm Conventions, United Nations Environment Program, 1219 Geneva, Switzerland; alexander.mangwiro@un.org

5 Department of Environmental Epidemiology, Institute of Industrial Ecological Sciences, University of Occupational and Environmental Health, Kitakyushu 807-8555, Japan; odgerel@med.uoeh-u.ac.jp

6 Department of Anatomical Pathology, Concord Repatriation General Hospital, Concord, NSW 2139, Australia; Kenneth.lee@health.nsw.gov.au

7 Asbestos Diseases Research Foundation, Concord, NSW 2139, Australia; peter.tighe08@gmail.com

8 International Commission on Occupational Health, 20122 Milan, Italy; jstakala@gmail.com

9 School of Public Health, The University of Sydney, Sydney, NSW 2006, Australia; tim.driscoll@sydney.edu.au

10 University of Occupational and Environmental Health, Kitakyushu 807-8555, Japan

* Correspondence: ken.takahashi@adri.org.au

Abstract: Worldwide, 230,000+ people die annually from asbestos-related diseases (ARDs). The World Health Organization (WHO) recommends that countries develop a National Asbestos Profile (NAP) to eliminate ARDs. For 195 countries, we assessed the global status of NAPs (A: bona fide NAP, B: proxy NAP, C: relevant published information, D: no relevant information) by national income (HI: high, UMI: upper-middle, LMI: lower-middle, LI: low), asbestos bans (banned, no-ban) and public data availability. Fourteen ( $7 \%$ of 195 ) countries were category A (having a bona fide NAP), while 98,51 and 32 countries were categories B, C and D, respectively. Of the 14 category-A countries, 8, 3 and 3 were LMI, UMI and HI, respectively. Development of a bona fide NAP showed no gradient by national income. The proportions of countries having a bona fide NAP were similar between asbestos-banned and no-ban countries. Public databases useful for developing NAPs contained data for most countries. Irrespective of the status of national income or asbestos ban, most countries have not developed a NAP despite having the potential. The global status of NAP is suboptimal. Country-level data on asbestos and ARDs in public databases can be better utilized to develop NAPs for globally eliminating ARDs.

Keywords: asbestos; policy; World Health Organization; International Labor Organization; National Asbestos Profile; prevention; mesothelioma

\section{Introduction}

A recent Global Burden of Disease (GBD) study estimated that each year more than 230,000 people die from diseases caused by occupational exposure to asbestos [1]. In 2006, the World Health Organization (WHO) declared that the most efficient way to eliminate asbestos-related diseases (ARDs) is to stop using all types of asbestos [2]. The following year, the WHO and the International Labor Organization (ILO) jointly formulated the National Program for the Elimination of Asbestos-Related Diseases (NPEAD) [3,4] to assist countries in establishing their respective national programs.

The National Asbestos Profile (NAP) was annexed to the NPEAD as a template to support the development of country profiles consisting of 18 items related to legislation, 
asbestos use, ARD status and risk assessment. As such, the NAP is an internationally standardized instrument that is designed to define the baseline situation of a country and measure its progress towards eliminating ARDs. In 2014, the WHO reiterated the 2006 declaration and published the NAP for the second time. Of the 18 NAP items, four and six items are related to the status of asbestos use and ARDs, respectively. Information and data related to asbestos use and ARDs are thus essential for countries to develop a NAP.

Asbestos use is declining at the global level, but national situations range from "totally banned" to "mining and exporting raw asbestos," or "manufacturing and/or using asbestos-containing products." Almost 70 countries/territories have adopted asbestos bans to date [5], but this is skewed towards developed (i.e., higher-income) countries. Many developing (i.e., lower-income) countries have been slow to reduce, let alone ban, the use of asbestos [6]. When countries use asbestos, their country-level volume and rate of use correlate well with the subsequent disease burden and rates of ARD [7,8].

The national situations of ARDs also vary, with some countries having no data while others report data of irregular quality. Based on data reported by 83 member states of the $\mathrm{WHO}$, the worldwide age-adjusted mortality rate of mesothelioma increased $5.4 \%$ annually from 1994 to 2008 [9]. An updated analysis continued to show a general increase of the ageadjusted mortality rate, based on data judged to be "reliable" from 59 member states [10]. A GBD study estimated an 82\% increase in global mesothelioma deaths from 1990 to 2016 [11]. However, reliable data on mesothelioma are not available from developing countries that continue to use large amounts of asbestos [12].

The development of NAPs will not only enable countries to monitor progress towards ARD elimination but also encourage countries to learn from each other's experiences and collectively promote the global elimination of ARDs. However, at present, there is no information on the global status of NAPs, let alone factors that encourage countries to develop (or inhibit countries from developing) their NAPs. Thus, the objective of this study was to assess the extent to which countries developed NAPs, or had the potential to do so, in relation to baseline factors such as national income status, asbestos bans and the availability of public data that can be used to develop a NAP.

\section{Materials and Methods}

We analyzed the status of information and data for 195 countries comprising 193 United Nations (UN) Member States [13] and two regional entities, Taiwan and Hong Kong. In our search of NAPs and related information, we explored the World Wide Web using English, German, French and Spanish. We also communicated with contacts of the coauthors, which included the current and former staff of international organizations, governments and non-government organizations. To determine the status of NAPs that corresponded to the countries, we applied the following criteria, which were ordinally categorized and mutually exclusive (Table 1):

When a document was identified as a bona fide NAP, a copy was obtained by downloading or requesting it from the concerned parties.

Two authors (DA, KT) rated the NAP statuses and thereby grouped the countries into four categories: A (country that has a bona fide NAP), B (country that does not have a bona fide NAP but has a proxy NAP), C (country that has neither a bona fide nor proxy NAP but has relevant published information) and $\mathrm{D}$ (country that has no relevant information). A disagreement between the two raters was reconciled by rechecking their ratings and, if the disagreement persisted, having a third author (SF) act as the tiebreaking rater to establish the final rating (there were three instances).

As basic characteristics, we grouped the analyzed countries as high income, uppermiddle income, lower-middle income and low income based on the Income Classification of the World Bank [14]. Regions were based on the WHO region designation [15]. Regarding the status (banned or no-ban) and year of asbestos ban, we referred to the list of Current Asbestos Bans on the website of the International Ban Asbestos Secretariat [5]. 
Table 1. Country and Document Categories.

\begin{tabular}{|c|c|c|}
\hline $\begin{array}{l}\text { Country } \\
\text { Category }\end{array}$ & Document Category & Document Description \\
\hline A & "bona fide $\mathrm{NAP}^{\prime}$ & $\begin{array}{l}\text { a single document that describes the national situation of } \\
\text { asbestos and asbestos-related diseases (ARDs) in adherence } \\
\text { to the NAP format published by the WHO/ILO }\end{array}$ \\
\hline B & "proxy NAP" & $\begin{array}{l}\text { a single document or multiple documents that describe the } \\
\text { national situation of asbestos and ARDs but does (do) not } \\
\text { satisfy the criterion for a bona fide NAP; * includes } \\
\text { government statements and/or decrees, scientific articles } \\
\text { and third-party organization reports }\end{array}$ \\
\hline $\mathrm{C}$ & $\begin{array}{l}\text { "relevant published } \\
\text { information" }\end{array}$ & $\begin{array}{l}\text { information that does not satisfy the criteria for a bona fide or } \\
\text { proxy NAP but refers to asbestos and/or ARDs; includes } \\
\text { online information on asbestos as part of wider } \\
\text { occupational health and safety policies, toxic chemical } \\
\text { waste management policies, ARD case studies and media } \\
\text { releases on asbestos and/or ARDs }\end{array}$ \\
\hline $\mathrm{D}$ & $\begin{array}{l}\text { "no relevant } \\
\text { information" }\end{array}$ & status that lacked any of the above \\
\hline
\end{tabular}

${ }^{*}$ A proxy NAP was defined to be compatible in content with a bona fide NAP without satisfying the criterion of adhering to the NAP format published by the WHO/ILO.

To assess the availability of data that can be used to develop a NAP, we used the following: two sources of asbestos-related data, namely, (1) consumption of raw asbestos in the United States Geological Survey database (USGS) [16] and (2) import of asbestoscontaining material, textiles and friction material in the United Nations International Trade Statistics Database (UN Comtrade) [17]; and four sources of disease-related data, namely, (1) reported mortality of mesothelioma or asbestosis in the WHO Mortality Database (MDB) [18], (2) estimated incidence of mesothelioma in the GBD studies [1], (3) estimated mortality of mesothelioma in the WHO Global Health Estimates database (GHE) [19] and (4) reported or estimated mortality of mesothelioma in the WHO Global Cancer Observatory (GCO) [20].

All data sources were publicly available. Microsoft Excel Version 16 (Microsoft Corporation, Washington DC, USA) was used to compile and analyze all data.

\section{Results}

Table 2 shows the basic characteristics of 195 countries grouped by NAP status. Of them, $14(7 \%)$ had a bona fide NAP (category A), 98 (50\%) did not have a bona fide NAP but had a proxy NAP (category B), $51(26 \%)$ had neither a bona fide nor proxy NAP but had other relevant published information (category C), and $32(16 \%)$ had no relevant published information (category D). Of the 14 countries that had a bona fide NAP (category A), most were LMI countries $(n=8)$, followed by UMI countries $(n=3)$ and HI countries $(n=3)$, as per the national income status. In terms of region, seven, four and three countries were in the Western Pacific, South East Asia and Europe, respectively. In terms of asbestos ban status, five countries had bans, while nine did not. The NAP categories with the highest proportion of countries by income status were B (78\%), B (52\%), C (33\%) and D (41\%) in the HI, UMI, LMI and LI categories, respectively. Of the 32 countries that had no relevant published information (category D), the greatest proportion corresponded to LI countries, followed sequentially by LMI, UMI and HI countries. 
Table 2. Basic characteristics of analyzed countries by the status of their National Asbestos Profile (NAP).

\begin{tabular}{|c|c|c|c|c|c|c|c|c|c|c|c|c|c|}
\hline \multirow[b]{2}{*}{ Country Category } & \multirow{2}{*}{$\begin{array}{l}\text { Number of } \\
\text { Countries }\end{array}$} & \multicolumn{3}{|c|}{ Income Category $^{1}$} & \multirow[b]{2}{*}{ LI } & \multicolumn{4}{|c|}{ Region } & \multirow[b]{2}{*}{ Africa } & \multirow[b]{2}{*}{$\begin{array}{c}\text { East } \\
\text { Mediterranean }\end{array}$} & \multicolumn{2}{|c|}{ Status of Asbestos Bar } \\
\hline & & HI & UMI & LMI & & $\begin{array}{l}\text { Western } \\
\text { Pacific }\end{array}$ & $\begin{array}{l}\text { South East } \\
\text { Asia }\end{array}$ & Europe & Americas & & & Banned & No-Ban \\
\hline \multirow{2}{*}{ A: Countries that have bona fide NAP ${ }^{2}$} & 14 & 3 & 3 & 8 & 0 & 7 & 4 & 3 & 0 & 0 & 0 & 5 & 9 \\
\hline & $(7 \%)$ & $(5 \%)$ & $(6 \%)$ & $(16 \%)$ & $(0 \%)$ & $(28 \%)$ & $(36 \%)$ & $(6 \%)$ & $(0 \%)$ & $(0 \%)$ & $(0 \%)$ & $(8 \%)$ & $(7 \%)$ \\
\hline \multirow{2}{*}{$\begin{array}{l}\text { B: Countries that do not have bona fide } \\
\text { NAP but have proxy NAP }{ }^{3}\end{array}$} & 98 & 49 & 28 & 15 & 6 & 17 & 4 & 39 & 14 & 12 & 12 & 51 & 47 \\
\hline & $(50 \%)$ & $(78 \%)$ & $(52 \%)$ & $(31 \%)$ & $(21 \%)$ & $(68 \%)$ & $(36 \%)$ & $(72 \%)$ & $(40 \%)$ & $(26 \%)$ & $(57 \%)$ & $(78 \%)$ & $(36 \%)$ \\
\hline \multirow{2}{*}{$\begin{array}{l}\text { C: Countries that have neither bona } \\
\text { fide or proxy NAP but have other } \\
\text { relevant published information }\end{array}$} & 51 & 10 & 14 & 16 & 11 & 2 & 2 & 8 & 13 & 19 & 7 & 9 & 42 \\
\hline & $(26 \%)$ & $(16 \%)$ & $(26 \%)$ & $(33 \%)$ & $(38 \%)$ & $(8 \%)$ & $(18 \%)$ & $(15 \%)$ & $(37 \%)$ & $(40 \%)$ & $(33 \%)$ & $(14 \%)$ & $(32 \%)$ \\
\hline \multirow{2}{*}{$\begin{array}{l}\text { D: Countries with no relevant } \\
\text { published information }\end{array}$} & 32 & 1 & 9 & 10 & 12 & 1 & 1 & 4 & 8 & 16 & 2 & 0 & 32 \\
\hline & $(16 \%)$ & $(2 \%)$ & $(17 \%)$ & $(20 \%)$ & $(41 \%)$ & $(4 \%)$ & $(9 \%)$ & $(7 \%)$ & $(23 \%)$ & $(34 \%)$ & $(10 \%)$ & $(0 \%)$ & $(25 \%)$ \\
\hline All countries & $\begin{array}{c}195 \\
(100 \%)\end{array}$ & $\begin{array}{c}63 \\
(100 \%)\end{array}$ & $\begin{array}{c}54 \\
(100 \%)\end{array}$ & $\begin{array}{c}49 \\
(100 \%)\end{array}$ & $\begin{array}{c}29 \\
(100 \%)\end{array}$ & $\begin{array}{c}27 \\
(100 \%)\end{array}$ & $\begin{array}{c}11 \\
(100 \%)\end{array}$ & $\begin{array}{c}54 \\
(100 \%)\end{array}$ & $\begin{array}{c}35 \\
(100 \%)\end{array}$ & $\begin{array}{c}47 \\
(100 \%)\end{array}$ & $\begin{array}{c}21 \\
(100 \%)\end{array}$ & $\begin{array}{c}65 \\
(100 \%)\end{array}$ & $\begin{array}{c}130 \\
(100 \%)\end{array}$ \\
\hline
\end{tabular}

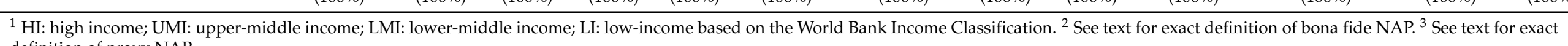
definition of proxy NAP. 
Of the 195 countries, 65 (33\%) countries had asbestos bans and $130(67 \%)$ countries did not. In the group of 65 asbestos-banned countries, $5(8 \%)$ had a bona fide NAP, 51 (78\%) had no bona fide NAP but had a proxy NAP, and $9(14 \%)$ had neither a bona fide nor proxy NAP but had other relevant published information. No asbestos-banned country lacked relevant published information. In the group of 130 no-ban countries, $9(7 \%)$ had a bona fide NAP, 47 (36\%) had no bona fide NAP but had a proxy NAP, $42(32 \%)$ had neither a bona fide nor proxy NAP but had other relevant published information, and $32(25 \%)$ had no relevant published information.

Figure 1 shows 14 countries with a bona fide NAP by their year of NAP publication and national income category. The embedded table supplements information on the region, the status and year of asbestos ban, and the authoring group/organization. (Table 3) All NAPs were published in the 2010 decade. The five NAP-published countries that banned asbestos were Australia, Japan, Bulgaria, Germany and North Macedonia. Of them, North Macedonia published their NAP in the year of their asbestos ban; the other four countries published their NAPs 8-14 years after their ban. Multiple stakeholders $(n=9)$ were the most frequent authoring group, followed by government $(n=8)$ and non-government $(n=6)$ organizations (the total exceeds 14 due to some countries being counted in multiple categories). All NAPs were written in English or had an English version except for the NAP of North Macedonia, which did not have an English version.

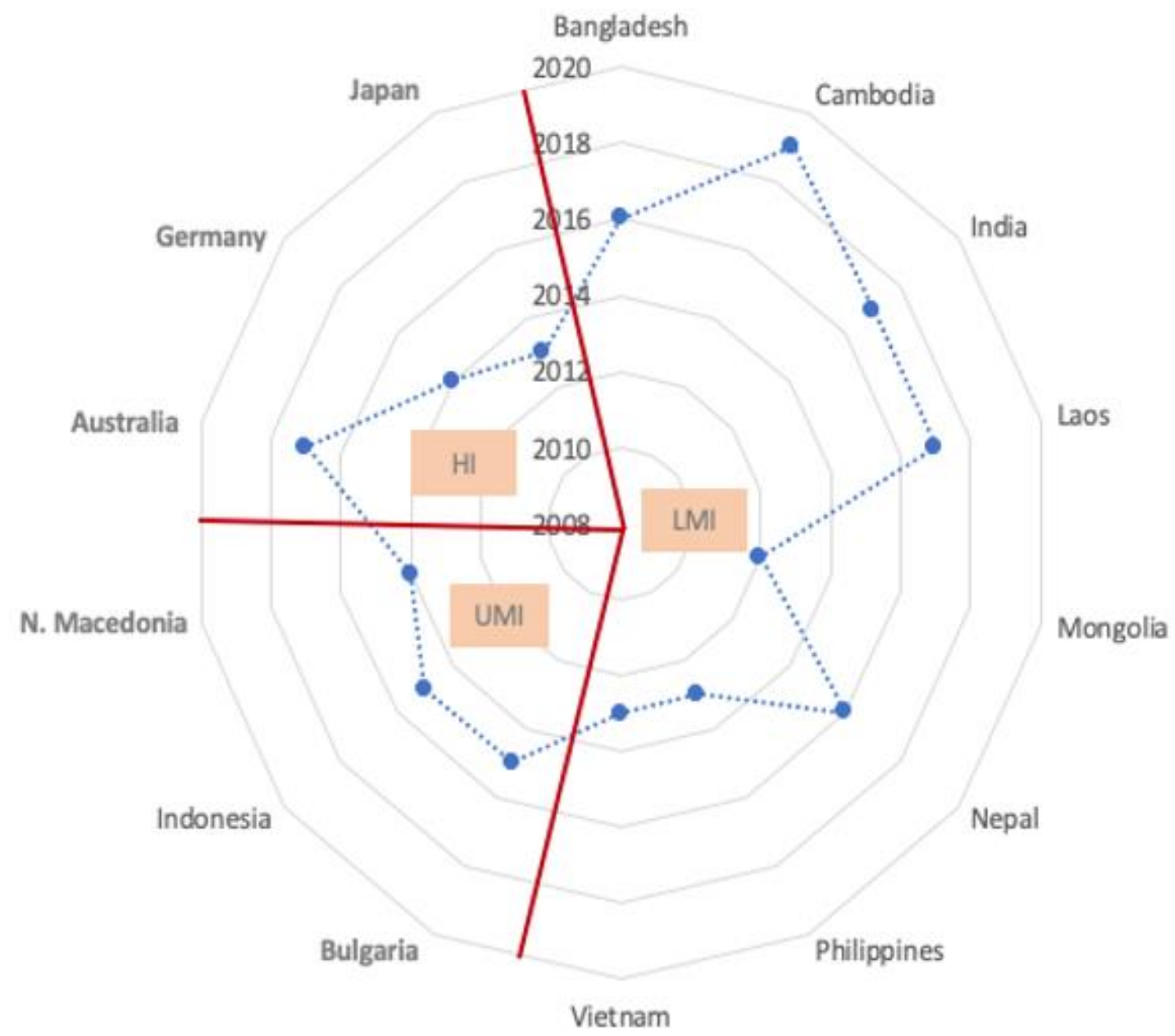

Figure 1. Countries that published a National Asbestos Profile, along with publication year and other characteristics. 
Table 3. Countries that published a National Asbestos Profile, Along With Publication Year and Other Characteristics.

\begin{tabular}{cccccc}
\hline Country & $\begin{array}{c}\text { NAP } \\
\text { Publication Year }\end{array}$ & $\begin{array}{c}\text { National Income } \\
\text { Category }\end{array}$ & Region ${ }^{\mathbf{2}}$ & Asbestos Ban & Authors ${ }^{3}$ \\
\hline Australia & 2017 & HI & WP & 2003 & G \\
Bangladesh & 2016 & LMI & SEA & No-ban & NG \\
Bulgaria & 2015 & UMI & EUR & 2005 & G \\
Cambodia & 2019 & LMI & WP & No-ban & G, MS \\
Germany & 2014 & HI & EUR & 2005 & G \\
India & 2017 & LMI & SEA & No-ban & NG \\
Indonesia & 2015 & UMI & SEA & No-ban & NG, MS \\
Japan & 2013 & HI & WP & 2007 & NG, MS \\
Laos & 2017 & LMI & WP & No-ban & G, MS \\
North Macedonia & 2014 & UMI & EUR & 2014 & NG, MS \\
Mongolia & 2012 & LMI & WP & No-ban & G, MS \\
Nepal & 2016 & LMI & SEA & No-ban & NG, MS \\
Philippines & 2013 & LMI & WP & No-ban & G, MS \\
Vietnam & 2013 & LMI & WP & No-ban & G, MS \\
\hline
\end{tabular}

${ }^{1}$ HI: High Income; UMI: Upper-Middle Income; LMI: Lower-Middle Income; ${ }^{2}$ WPR: Western Pacific; SEAR: South-East Asia; EUR: Europe; ${ }^{3}$ G: Government; NG: Non-Government; MS: Multiple Stakeholders.

Table 4 shows the relationship between the NAP category and the availability of data that can be used for a NAP. Asbestos data were available from two data sources: (1) the USGS database on raw asbestos consumption; and (2) the UN Comtrade data on asbestos-containing materials. The overall data availability was $85 \%(165 / 195)$ and $92 \%$ $(179 / 195)$ of all countries, respectively. When stratified by NAP category, USGS data on raw asbestos consumption were available for $100 \%(14 / 14), 85 \%(83 / 98), 84 \%(43 / 51)$ and $78 \%(25 / 32)$ of category A, B, C and D countries, respectively. Similarly, UN Comtrade data on asbestos-containing materials were available for 100\% (14/14), 93\% (91/98), 90\% $(46 / 51)$ and $88 \%(28 / 32)$ of category A, B, C and D countries, respectively.

Disease data were available from four data sources: (1) the MDB data on reported mortality of mesothelioma or asbestosis; (2) the GBD data on the estimated incidence of mesothelioma; (3) the GHE data on estimated mortality of mesothelioma; and (4) the GCO data on reported or estimated mortality of mesothelioma. The overall data availability was $49 \%(96 / 195), 95 \%(186 / 195), 91 \%(178 / 195)$ and $69 \%(134 / 195)$ of all countries, respectively. When stratified by NAP category, data availability was generally better for categories A and B and worst for category D. For example, the MDB data on reported mortality of mesothelioma or asbestosis were available for 50\% (7/14), 64\% (63/98), 37\% $(19 / 51)$ and $22 \%(7 / 32)$ of countries in categories A, B, C and D, respectively.

Table A1 lists the 14 bona fide NAPs and their references. Table A2 summarizes the data availability for each country across all six databases. Table A3 outlines the original NAP according each item (I-1 to I-18) to public data sources that can be utilized. Data for legislation-related items (I-1, I-15, I-16) were generally not available from international sources and thus needed to be sought from national sources. Data for asbestos-related items (I-2 to I-5) were generally available from the international databases mentioned above. Data for disease-related items (I-9 to I-12) were available from the international databases mentioned above. Although data for I-17 were generally not available from any source for most countries, data for I-18 were available in PubMed. Data for risk assessment (I-6 to I-8, I-13, I-14) were sometimes available from national sources. 
Table 4. Availability of data that can be used for NAPs in public databases.

\begin{tabular}{|c|c|c|c|c|c|c|}
\hline \multirow[b]{3}{*}{ Country Category } & \multicolumn{6}{|c|}{ Data Availability } \\
\hline & \multicolumn{2}{|c|}{ Asbestos Data } & \multicolumn{4}{|c|}{ Disease Data } \\
\hline & $\begin{array}{c}\text { Consumption of Raw } \\
\text { Asbestos < USGS }{ }^{1}> \\
(\text { Row \%) }\end{array}$ & $\begin{array}{c}\text { Asbestos-Containing } \\
\text { Material, Cement, } \\
\text { Textiles or Friction } \\
\text { Material < UN } \\
\text { Comtrade }^{2}>(\text { row \%) }\end{array}$ & $\begin{array}{l}\text { Reported Mortality of } \\
\text { Mesothelioma or } \\
\text { Asbestosis }{ }^{3}<\text { WHO } \\
\text { MDB }^{3}>(\text { Row } \%)\end{array}$ & $\begin{array}{c}\text { Estimated Incidence of } \\
\text { Mesothelioma < GBD } \\
>\text { (Row \%) }\end{array}$ & $\begin{array}{c}\text { Estimated Mortality of } \\
\text { Mesothelioma }<\text { WHO } \\
\text { GHE }^{5}>(\text { Row } \%)\end{array}$ & $\begin{array}{c}\text { Reported or Estimated } \\
\text { Mortality of } \\
\text { Mesothelioma }<\text { WHO } \\
\text { GCO }^{6}>(\text { Row } \%)\end{array}$ \\
\hline $\mathrm{A}(n=14)$ & $14(100 \%)$ & $14(100 \%)$ & $7(50 \%)$ & $14(100 \%)$ & $14(100 \%)$ & $13(93 \%)$ \\
\hline$C(n=51)$ & $43(84 \%)$ & $46(90 \%)$ & $19(37 \%)$ & $49(96 \%)$ & $47(92 \%)$ & $27(53 \%)$ \\
\hline $\mathrm{D}(n=32)$ & $25(78 \%)$ & $28(88 \%)$ & $7(22 \%)$ & $32(100 \%)$ & $30(94 \%)$ & $17(53 \%)$ \\
\hline All countries $(n=195)$ & $165(85 \%)$ & $179(92 \%)$ & $96(49 \%)$ & $186(95 \%)$ & $178(91 \%)$ & $134(69 \%)$ \\
\hline
\end{tabular}

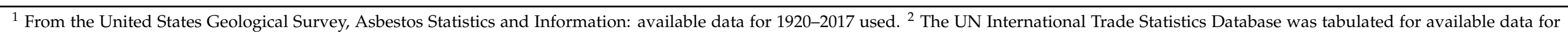

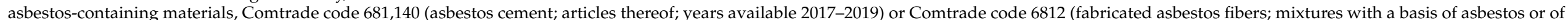

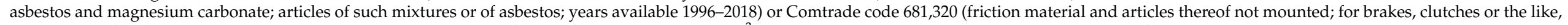

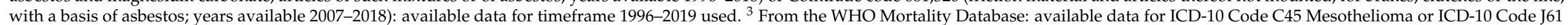

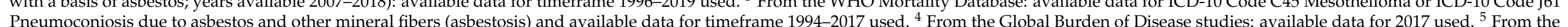

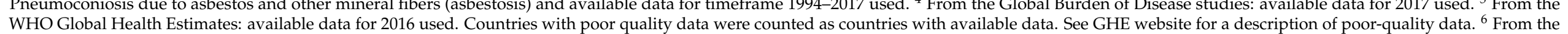
WHO Global Cancer Observatory: available data for 2018 used. Note that historical data not available due to differences in estimation methods. 


\section{Discussion}

A total of 14 (7\% of 195) countries developed bona fide NAPs (category A). The development of a bona fide NAP showed no gradient by national income: LMI countries comprised the highest proportion (16\%) of countries that published a bona fide NAP, followed by UMI $(6 \%)$ and HI (5\%) countries, with no bona fide NAP developed by an LI country to date. At the opposite extreme, 32 (16\% of 195) countries had no relevant published information (category D), and this showed a gradient with the national income category: LI countries comprised the highest proportion with no relevant published information, followed sequentially by LMI, UMI and HI countries. Furthermore, a comparatively poorer status of NAPs (i.e., categories $C$ and D combined) correlated with lower national income. Therefore, our study demonstrated that although the NAP status was generally related to the national income status, the development of a bona fide NAP was unrelated to the national income status in all but LI countries.

Ninety-eight ( $50 \%$ of 195 ) countries did not have a bona fide NAP but did have a proxy NAP (category B). As a proxy NAP was defined as being compatible in content with a bona fide NAP, they should be similar in their resources and information. It is thus reasonable to assume that the 98 countries (in category B) had the full potential (i.e., resources and information) to develop a bona fide NAP. A further 51 (26\% of 195) countries had neither a bona fide nor proxy NAP but had other relevant published information (category C) and thus could have had some potential to develop a bona fide NAP. In effect, a combined 149 (76\% of 195) countries had some or full potential to develop a NAP.

Two sources of data for asbestos and four sources of data for ARDs were available to develop a NAP. Importantly, these sources contained data for most of the countries, and there was a minimal gradient of data availability across the NAP categories (Table 4). A notable exception was the WHO MDB; this database compiles data reported by countries, and fewer than $50 \%$ of the countries were covered for mesothelioma mortality. However, estimated data can compensate for the lack of reported data, provided that a country indicates the nature of data that are incorporated in the NAP. The low number $(n=14)$ and proportion ( $7 \%$ ) of all countries that had developed a bona fide NAP should thus be viewed in consideration of the wide availability of country-level data on asbestos and ARDs.

Mesothelioma is widely accepted as an indicator disease caused by asbestos exposure, with at least $80 \%$ specificity [21]; it is thus a key item for a NAP. Although more than $50 \%$ of the countries did not report mesothelioma deaths to the WHO, estimates are currently available for more than $90 \%$ of the countries in the two data sources (Table 4). Although many lower-income countries started to consume asbestos recently, some of them may not have reached the generally accepted latency period of 30-40 years for mesothelioma [21]. Moreover, many lower-income countries have not yet acquired the technology/infrastructure to diagnose and report mesothelioma and thus may be "missing" the disease burden. It is important for countries lacking mesothelioma data to utilize these estimates; that said, it is also important that they understand the method of imputation to derive the estimates (e.g., asbestos use is commonly imputed) as well as their limitations [10].

The regional distribution of the 14 NAP-published countries was skewed, with the majority situated in Asia (seven in the Western Pacific and four in South-East Asia), three in Europe and none in the Americas, Africa or Eastern Mediterranean (Table 3). The regional preponderance may have been caused by a combination of "pull" and "push" factors. Possible pull factors are that Europe is the known current center of the ARD burden [22], and Asia has been implicated as the future "center" [23] of this burden due to its current heavy use of asbestos. Possible push factors include the WHO/ILO partnerships (e.g., the 2010 Parma Declaration on Environment and Health specified establishment of NPEAD for the member states of WHO-Europe [24]) and grass-roots initiatives on advocacy and technology transfer (e.g., the Asian Asbestos Initiative) [25]. On the other hand, proasbestos lobbies influence asbestos use in industrializing countries [6] and may present "opposing" factors. All these factors will impact the development (or lack thereof) of a NAP. 
In terms of the relationship between the NAP category and asbestos-ban status, the proportion of countries having a bona fide NAP was similarly low in asbestos-banned ( $8 \%$ or $5 / 65)$ and no-ban $(7 \%$ or $9 / 130)$ countries. The lack of association between the status of NAP and asbestos-ban is a positive finding because the acceptance of a NAP should not be limited to either asbestos-banned or no-ban countries. The NAP is an effective tool to outline the national situation on asbestos and ARDs. The development of a NAP benefits no-ban countries by informing the progress towards the adoption of an asbestos ban and benefits asbestos-banned countries by informing the progress in reducing exposure to in situ asbestos and transitioning to an asbestos-free society.

Most (56 [86\%] of 65) of the asbestos-banned countries had either a bona fide NAP or a proxy NAP (i.e., categories A and B combined), while more than half (74 [57\%] of 130) of noban countries had neither of the two (i.e., categories $C$ and D combined). Asbestos-banned countries may build a "knowledge base" of experience, information and data, which accumulate over the various phases of asbestos use, ban and post-ban. This knowledge base is likely to be documented in various forms, including laws, regulations, advisories, status reports and official statistics. These countries can thus capitalize on the abundant experience and resources to develop their NAPs. In contrast, no-ban countries may have a less extensive "knowledge base", fewer resources and less experience.

For the 14 existing NAPs, multiple stakeholder authorship was common, and government representatives were often involved, with others or on their own. This finding corroborates the importance of employing multidisciplinary expertise with government representation in developing a NAP. Governments routinely collect information on industry and the labor force and collect (albeit to a lesser extent) surveillance data on asbestos and ARDs. General information on industry and the labor force constitutes baseline information and may be documented in the NAP to provide a national context. However, the highest priority should be given to incorporating national surveillance data on asbestos and ARDs. It is also important to observe that an equal disease incidence in men and women, rather than higher incidence in men due to occupational exposure to asbestos, could also alert countries to potential environmental exposure. Future studies are needed to review the use of ARD database information from this perspective.

The major limitations of this study are as follows: (1) We assessed the global status of the development of NAPs, not their utilization. For example, the NAP can be used to further develop a national action plan. Such a theme, however, is fundamentally different and warrants a separate study. (2) We cannot rule out the possibility that we missed identifying an existing bona fide NAP. (3) Our authors were involved in developing several NAPs (SF for the NAP of Japan; PT for the NAP of Australia; KT for the NAPs of Japan, Vietnam and Australia); although this experience may have added perspective and insight to the present work, we may not have been able to eliminate bias in judging a NAP as bona fide or not. The scope of this study is limited to mesothelioma and asbestosis and databases that use reported and/or estimated mortality. We highlight usable data sources from credible organizations that can be used to help and inform future NAPs. Despite being useful as an indicator of the asbestos burden, any database that uses estimates or country-level proxy data as a method has limitations. A strength of this study is that we were able to analyze the status of NAP development for most countries of the world and offer a framework for more countries to develop a NAP.

\section{Conclusions}

In conclusion, the global status of NAPs is suboptimal. Irrespective of the status of national income or asbestos ban, most countries of the world have not developed a NAP despite having the potential (i.e., resources and information) to do so. Among the few countries that have developed a bona fide NAP, LMI and UMI countries outnumber HI countries. Country-level data on asbestos and ARDs in public databases can be utilized to develop a NAP. All countries should develop their NAP and use it to monitor progress 
towards eliminating ARDs, learn from the experience of other countries and contribute to promoting the global elimination of ARDs.

Author Contributions: Conceptualization, D.A. and K.T.; Data curation, D.A., S.F., A.D. and O.C.-O.; Formal analysis, D.A. and K.T.; Funding acquisition, K.T.; Investigation, D.A. and K.T.; Methodology, D.A. and K.T.; Project administration, D.A.; Resources, D.A.; Supervision, K.T.; Validation, S.F.; Visualization, D.A., O.C.-O. and K.T.; Writing-original draft, D.A. and K.T.; Writing-review \& editing, S.F., A.D., A.M., O.C.-O., K.L., P.T., J.T., T.D. and K.T. All authors have read and agreed to the published version of the manuscript.

Funding: This research was funded by the Regional Collaborations Program of the Australian Academy of Science.

Institutional Review Board Statement: Not applicable.

Informed Consent Statement: Not applicable.

Data Availability Statement: Data is available on request.

Acknowledgments: The authors thank V. Aleksova for assisting in the linguistic interpretation of the NAP of North Macedonia.

Conflicts of Interest: The authors declare no conflict of interest.

\section{Appendix A}

Table A1. List of bona fide National Asbestos Profiles and their References.

\begin{tabular}{|c|c|}
\hline Country & Reference \\
\hline Australia & $\begin{array}{l}\text { Asbestos Safety and Eradiation Agency. 2017. National Asbestos Profile for Australia. Available online: https://www. } \\
\text { asbestossafety.gov.au/sites/default/files/documents/2017-12/ASEA_National_Asbestos_Profile_interactive_Nov17.pdf } \\
\text { (accessed on } 11 \text { January 2021). [26] }\end{array}$ \\
\hline Bangladesh & $\begin{array}{l}\text { Bangladesh Occupational Safety, Health and Environment Foundation. 2016. National Asbestos Profile of Bangladesh. Obtained } \\
\text { via personal communication: } 20 \text { April 2020. [27] }\end{array}$ \\
\hline Bulgaria & $\begin{array}{l}\text { Vangelova, K.; Dimitrova, S.; Dimitrova, I. 2015. National Asbestos Profile of Bulgaria. Available online: } \\
\text { https://ncpha.government.bg/files/National\%20Asbestos\%20Profile_Bulgaria_2015-en.pdf (accessed on } 11 \text { January } \\
\text { 2021). [28] }\end{array}$ \\
\hline Cambodia & $\begin{array}{l}\text { Ministry of Labor and Vocational Training. 2019. Cambodia National Asbestos Profile. Personal Communication, 2020. [29] } \\
\text { Federal Institute for Occupational Health and Safety. 2014. National Asbestos Profile for Germany. Available online: }\end{array}$ \\
\hline Germany & $\begin{array}{l}\text { https:// www.baua.de/EN/Service/Publications/Report/Gd80.pdf?_blob=publicationFile\&v=8 (accessed on } 11 \text { January } \\
\text { 2021). [30] }\end{array}$ \\
\hline India & $\begin{array}{l}\text { People's Training \& Research and Centre. 2017. India: National Asbestos Profile. Available online: } \\
\text { https: / /amrc.org.hk/sites/default/files/NAP\%20India.pdf (accessed on } 11 \text { January 2021). [31] }\end{array}$ \\
\hline Indonesia & $\begin{array}{l}\text { Indonesia Ban Asbestos Network. 2017. National Asbestos Profile Indonesia. Obtained via personal communication: } 28 \text { April } \\
\text { 2020. [32] }\end{array}$ \\
\hline Japan & $\begin{array}{l}\text { Furuya, S.; Takahashi, K.; Mohaved, M.; Jiang, Y. 2013. National Asbestos Profile of Japan. Available online: } \\
\text { https://www.researchgate.net/publication/237839114_National_Asbestos_Profile_of_Japan_-_Based_on_the_National_ } \\
\text { Asbestos_Profile_by_the_ILO_and_the_WHO (accessed on } 11 \text { January 2021) [33] }\end{array}$ \\
\hline Laos & Laos Ministry of Industry and Commerce. 2017. National Asbestos Profile of Laos. Personal Communication, 2020. [34] \\
\hline North Macedonia & $\begin{array}{l}\text { Institute of Occupational Health of the Republic of Macedonia. 2014. National Asbestos Profile for the Republic of Macedonia. } \\
\text { Personal Communication, 2020. [35] }\end{array}$ \\
\hline Mongolia & $\begin{array}{l}\text { Health Sciences University of Mongolia. 2012. National Asbestos Profile of Mongolia. Personal Communication, 2020. [36] } \\
\text { Sah, R.C. 2016. National Asbestos Profile of Nepal. Available online: }\end{array}$ \\
\hline Nepal & $\begin{array}{l}\text { http://anroev.org/aban/wp-content/uploads/2016/10/National-Abestos-Profile-of-Nepal.pdf (accessed on } 11 \text { January } \\
\text { 2021). [37] }\end{array}$ \\
\hline Philippines & $\begin{array}{l}\text { Republic of Philippines, Environmental and Occupational Health Office. 2013. National Asbestos Profile Philippines. Available } \\
\text { online: https://www.informea.org/en/national-asbestos-profile-nap-philippines (accessed on } 11 \text { January 2021). [38] }\end{array}$ \\
\hline Vietnam & $\begin{array}{l}\text { Pham, V.H.; Tran, T.N.L.; Le, G.V.; Movahed, M.; Jiang, Y.; Pham, N.H.; Ogawa, H; Takahashi, K. Asbestos and asbestos-related } \\
\text { diseases in Vietnam: In reference to the International Labor Organization/World Health Organization National Asbestos } \\
\text { Profile. Saf. Health Work. 2013, 4, 117-121. doi:10.1016/j.shaw.2013.04.002. [39] }\end{array}$ \\
\hline
\end{tabular}


Table A2. Availability of Asbestos and Asbestos-Related-Diseases Data by Country and NAP Country Category.

\begin{tabular}{|c|c|c|c|c|c|c|c|c|c|c|}
\hline & \multirow[b]{2}{*}{ Countries $^{1}$} & \multirow[b]{2}{*}{$\begin{array}{c}\text { World Bank } \\
\text { Income Group }\end{array}$} & \multirow[b]{2}{*}{$\begin{array}{c}\text { Asbestos Ban } \\
\text { Status }^{3}\end{array}$} & \multirow[b]{2}{*}{$\begin{array}{l}\text { NAP Country } \\
\text { Category } 4\end{array}$} & \multicolumn{2}{|c|}{ Asbestos Data } & \multicolumn{4}{|c|}{ Disease Data } \\
\hline & & & & & $\begin{array}{c}\text { Consumption } \\
\text { of Raw } \\
\text { Asbestos } \\
\text { (USGS) }^{5}\end{array}$ & $\begin{array}{l}\text { Asbestos- } \\
\text { Containing } \\
\text { Material (UN } \\
\text { Comtrade) }^{6}\end{array}$ & $\begin{array}{c}\text { Reported } \\
\text { Mortality of } \\
\text { Mesothelioma } \\
\text { or Asbestosis } \\
\text { (WHO MDB) }^{7}\end{array}$ & $\begin{array}{l}\text { Estimated } \\
\text { Incidence of } \\
\text { Mesothelioma } \\
\text { (GBD) }{ }^{8}\end{array}$ & $\begin{array}{c}\text { Estimated } \\
\text { Mortality of } \\
\text { Mesothelioma } \\
\text { (WHO GHE) }^{9}\end{array}$ & $\begin{array}{c}\text { Reported or } \\
\text { estimated } \\
\text { Mortality of } \\
\text { Mesothelioma } \\
\text { (WHO GCO) }^{10}\end{array}$ \\
\hline 1 & Afghanistan & LI & No-Ban & $\mathrm{C}$ & Yes & No & No & Yes & Yes & Yes \\
\hline 2 & Albania & UMI & No-Ban & $\mathrm{C}$ & Yes & Yes & No & Yes & Yes & Yes \\
\hline 3 & Algeria & LMI & Ban & $\mathrm{C}$ & Yes & Yes & No & Yes & Yes & Yes \\
\hline 4 & Andorra & $\mathrm{HI}$ & No-Ban & $\mathrm{C}$ & No & Yes & No & Yes & No & No \\
\hline 5 & Angola & LMI & No-Ban & $\mathrm{D}$ & Yes & Yes & No & Yes & Yes & Yes \\
\hline 6 & Antigua and Barbuda & $\mathrm{HI}$ & No-Ban & $\mathrm{D}$ & Yes & Yes & No & Yes & No & No \\
\hline 7 & Argentina & UMI & Ban & $\mathrm{B}$ & Yes & Yes & Yes & Yes & Yes & Yes \\
\hline 8 & Armenia & UMI & No-Ban & $\mathrm{D}$ & Yes & Yes & Yes & Yes & Yes & Yes \\
\hline 9 & Australia & $\mathrm{HI}$ & Ban & $\mathrm{A}$ & Yes & Yes & Yes & Yes & Yes & Yes \\
\hline 10 & Austria & $\mathrm{HI}$ & Ban & $\mathrm{B}$ & Yes & Yes & Yes & Yes & Yes & Yes \\
\hline 11 & Azerbaijan & UMI & No-Ban & C & Yes & Yes & No & Yes & Yes & Yes \\
\hline 12 & Bahamas & $\mathrm{HI}$ & No-Ban & $\mathrm{C}$ & Yes & Yes & Yes & No & Yes & No \\
\hline 13 & Bahrain & $\mathrm{HI}$ & Ban & B & No & Yes & Yes & Yes & Yes & Yes \\
\hline 14 & Bangladesh & LMI & No-Ban & $\mathrm{A}$ & Yes & Yes & No & Yes & Yes & Yes \\
\hline 15 & Barbados & $\mathrm{HI}$ & No-Ban & B & Yes & Yes & Yes & Yes & Yes & No \\
\hline 16 & Belarus & UMI & No-Ban & $\mathrm{D}$ & Yes & Yes & No & Yes & Yes & Yes \\
\hline 17 & Belgium & $\mathrm{HI}$ & Ban & $\mathrm{B}$ & Yes & Yes & Yes & Yes & Yes & Yes \\
\hline 18 & Belize & UMI & No-Ban & $\mathrm{D}$ & Yes & Yes & Yes & Yes & Yes & No \\
\hline 19 & Benin & LMI & No-Ban & $\mathrm{D}$ & Yes & Yes & No & Yes & Yes & Yes \\
\hline 20 & Bhutan & LMI & No-Ban & $\mathrm{C}$ & Yes & Yes & No & Yes & Yes & No \\
\hline 21 & Bolivia & LMI & No-Ban & $\mathrm{B}$ & Yes & Yes & Yes & Yes & Yes & Yes \\
\hline 22 & Bosnia and Herzegovina & UMI & No-Ban & $\mathrm{B}$ & Yes & Yes & Yes & Yes & Yes & Yes \\
\hline 23 & Botswana & UMI & No-Ban & $\mathrm{C}$ & Yes & Yes & No & Yes & Yes & No \\
\hline 24 & Brazil & UMI & Ban & $\mathrm{B}$ & Yes & Yes & Yes & Yes & Yes & Yes \\
\hline 25 & Brunei & $\mathrm{HI}$ & Ban & $\mathrm{C}$ & Yes & Yes & No & Yes & Yes & No \\
\hline 26 & Bulgaria & UMI & Ban & A & Yes & Yes & Yes & Yes & Yes & Yes \\
\hline 27 & Burkina Faso & LI & No-Ban & $\mathrm{D}$ & No & Yes & No & Yes & Yes & Yes \\
\hline 28 & Burundi & LI & No-Ban & $\mathrm{D}$ & Yes & Yes & No & Yes & Yes & Yes \\
\hline 29 & Cambodia & LMI & No-Ban & A & Yes & Yes & No & Yes & Yes & Yes \\
\hline 30 & Cameroon & LMI & No-Ban & $\mathrm{D}$ & Yes & Yes & No & Yes & Yes & No \\
\hline 31 & Canada & $\mathrm{HI}$ & Ban & $\mathrm{B}$ & Yes & Yes & Yes & Yes & Yes & Yes \\
\hline 32 & Cape Verde & LMI & No-Ban & $\mathrm{C}$ & No & Yes & No & Yes & Yes & No \\
\hline 33 & Central African Republic & LI & No-Ban & $\mathrm{D}$ & No & Yes & No & Yes & Yes & No \\
\hline 34 & Chad & LI & No-Ban & $\mathrm{C}$ & Yes & No & No & Yes & Yes & No \\
\hline 35 & Chile & $\mathrm{HI}$ & Ban & $\mathrm{B}$ & Yes & Yes & Yes & Yes & Yes & Yes \\
\hline 36 & China & UMI & No-Ban & B & Yes & Yes & No & Yes & Yes & Yes \\
\hline
\end{tabular}


Table A2. Cont.

\begin{tabular}{|c|c|c|c|c|c|c|c|c|c|c|}
\hline & \multirow[b]{2}{*}{ Countries $^{1}$} & \multirow[b]{2}{*}{$\begin{array}{c}\text { World Bank } \\
\text { Income Group }\end{array}$} & \multirow[b]{2}{*}{$\begin{array}{c}\text { Asbestos Ban } \\
\text { Status }^{3}\end{array}$} & \multirow[b]{2}{*}{$\begin{array}{l}\text { NAP Country } \\
\text { Category } 4\end{array}$} & \multicolumn{2}{|c|}{ Asbestos Data } & \multicolumn{4}{|c|}{ Disease Data } \\
\hline & & & & & $\begin{array}{c}\text { Consumption } \\
\text { of Raw } \\
\text { Asbestos } \\
\text { (USGS) }^{5}\end{array}$ & $\begin{array}{l}\text { Asbestos- } \\
\text { Containing } \\
\text { Material (UN } \\
\text { Comtrade) }^{6}\end{array}$ & $\begin{array}{c}\text { Reported } \\
\text { Mortality of } \\
\text { Mesothelioma } \\
\text { or Asbestosis } \\
\text { (WHO MDB) }^{7}\end{array}$ & $\begin{array}{l}\text { Estimated } \\
\text { Incidence of } \\
\text { Mesothelioma } \\
\text { (GBD) }\end{array}$ & $\begin{array}{c}\text { Estimated } \\
\text { Mortality of } \\
\text { Mesothelioma } \\
\text { (WHO GHE) }^{9}\end{array}$ & $\begin{array}{c}\text { Reported or } \\
\text { estimated } \\
\text { Mortality of } \\
\text { Mesothelioma } \\
\text { (WHO GCO) }{ }^{10}\end{array}$ \\
\hline 37 & Colombia & UMI & Ban & B & Yes & Yes & Yes & Yes & Yes & Yes \\
\hline 38 & Comoros & LMI & No-Ban & $\mathrm{D}$ & No & Yes & No & Yes & Yes & No \\
\hline 39 & Congo-Brazzaville & LMI & No-Ban & $\mathrm{D}$ & Yes & Yes & No & Yes & Yes & Yes \\
\hline 40 & Congo-Kinshasa (DR Congo) & LI & No-Ban & $\mathrm{C}$ & Yes & No & No & Yes & No & Yes \\
\hline 41 & Costa Rica & UMI & No-Ban & $\mathrm{B}$ & Yes & Yes & Yes & Yes & Yes & No \\
\hline 42 & Côte d'Ivoire & LMI & No-Ban & C & Yes & Yes & No & Yes & Yes & Yes \\
\hline 43 & Croatia & $\mathrm{HI}$ & Ban & $\mathrm{B}$ & Yes & Yes & Yes & Yes & Yes & Yes \\
\hline 44 & Cuba & UMI & No-Ban & $\mathrm{C}$ & Yes & Yes & Yes & Yes & Yes & Yes \\
\hline 45 & Cyprus & $\mathrm{HI}$ & Ban & $\mathrm{B}$ & Yes & Yes & Yes & Yes & Yes & Yes \\
\hline 46 & Czech Republic & $\mathrm{HI}$ & Ban & B & Yes & Yes & Yes & Yes & Yes & Yes \\
\hline 47 & Denmark & $\mathrm{HI}$ & Ban & B & Yes & Yes & Yes & Yes & Yes & Yes \\
\hline 48 & Djibouti & LMI & Ban & $\mathrm{C}$ & Yes & No & No & Yes & Yes & No \\
\hline 49 & Dominica & UMI & No-Ban & $\mathrm{D}$ & Yes & Yes & No & Yes & Yes & No \\
\hline 50 & Dominican Republic & UMI & No-Ban & $\mathrm{D}$ & Yes & Yes & Yes & Yes & Yes & Yes \\
\hline 51 & Ecuador & UMI & No-Ban & $\mathrm{B}$ & Yes & Yes & Yes & Yes & Yes & Yes \\
\hline 52 & Egypt & LMI & Ban & B & Yes & Yes & Yes & Yes & Yes & Yes \\
\hline 53 & El Salvador & LMI & No-Ban & $\mathrm{D}$ & Yes & Yes & Yes & Yes & Yes & No \\
\hline 54 & Equatorial Guinea & UMI & No-Ban & $\mathrm{D}$ & No & No & No & Yes & Yes & No \\
\hline 55 & Eritrea & LI & No-Ban & $\mathrm{D}$ & Yes & No & No & Yes & Yes & Yes \\
\hline 56 & Estonia & $\mathrm{HI}$ & Ban & B & Yes & Yes & Yes & Yes & Yes & Yes \\
\hline 57 & Eswatini Swaziland & LMI & No-Ban & $\mathrm{C}$ & Yes & Yes & No & Yes & Yes & No \\
\hline 58 & Ethiopia & LI & No-Ban & $\mathrm{C}$ & Yes & Yes & No & Yes & Yes & Yes \\
\hline 59 & Fiji & UMI & No-Ban & $\mathrm{B}$ & Yes & Yes & Yes & Yes & No & No \\
\hline 60 & Finland & $\mathrm{HI}$ & Ban & B & Yes & Yes & Yes & Yes & Yes & Yes \\
\hline 61 & France & $\mathrm{HI}$ & Ban & B & Yes & Yes & Yes & Yes & Yes & Yes \\
\hline 62 & Gabon & UMI & Ban & $\mathrm{C}$ & Yes & Yes & No & Yes & Yes & No \\
\hline 63 & Gambia & LI & No-Ban & $\mathrm{C}$ & No & Yes & No & Yes & Yes & No \\
\hline 64 & Georgia & UMI & No-Ban & $\mathrm{C}$ & Yes & Yes & Yes & Yes & Yes & Yes \\
\hline 65 & Germany & $\mathrm{HI}$ & Ban & $\mathrm{A}$ & Yes & Yes & Yes & Yes & Yes & Yes \\
\hline 66 & Ghana & LMI & No-Ban & $\mathrm{B}$ & Yes & Yes & No & Yes & Yes & Yes \\
\hline 67 & Greece & $\mathrm{HI}$ & Ban & B & Yes & Yes & Yes & Yes & Yes & Yes \\
\hline 68 & Grenada & UMI & No-Ban & $\mathrm{C}$ & No & Yes & Yes & Yes & No & No \\
\hline 69 & Guatemala & UMI & No-Ban & $\mathrm{C}$ & Yes & Yes & Yes & Yes & Yes & No \\
\hline 70 & Guinea & LI & No-Ban & $\mathrm{D}$ & Yes & Yes & No & Yes & Yes & No \\
\hline 71 & Guinea-Bissau & LI & No-Ban & $\mathrm{D}$ & No & Yes & No & Yes & Yes & No \\
\hline 72 & Guyana & UMI & No-Ban & $\mathrm{C}$ & Yes & Yes & Yes & Yes & Yes & No \\
\hline
\end{tabular}


Table A2. Cont.

\begin{tabular}{|c|c|c|c|c|c|c|c|c|c|c|}
\hline & \multirow[b]{2}{*}{ Countries $^{1}$} & \multirow[b]{2}{*}{$\begin{array}{c}\text { World Bank } \\
\text { Income Group }\end{array}$} & \multirow[b]{2}{*}{$\begin{array}{c}\text { Asbestos Ban } \\
\text { Status }^{3}\end{array}$} & \multirow[b]{2}{*}{$\begin{array}{l}\text { NAP Country } \\
\text { Category } 4\end{array}$} & \multicolumn{2}{|c|}{ Asbestos Data } & \multicolumn{4}{|c|}{ Disease Data } \\
\hline & & & & & $\begin{array}{c}\text { Consumption } \\
\text { of Raw } \\
\text { Asbestos } \\
\text { (USGS) }^{5}\end{array}$ & $\begin{array}{l}\text { Asbestos- } \\
\text { Containing } \\
\text { Material (UN } \\
\text { Comtrade) }^{6}\end{array}$ & $\begin{array}{c}\text { Reported } \\
\text { Mortality of } \\
\text { Mesothelioma } \\
\text { or Asbestosis } \\
\text { (WHO MDB) }^{7}\end{array}$ & $\begin{array}{l}\text { Estimated } \\
\text { Incidence of } \\
\text { Mesothelioma } \\
\text { (GBD) }{ }^{8}\end{array}$ & $\begin{array}{c}\text { Estimated } \\
\text { Mortality of } \\
\text { Mesothelioma } \\
\text { (WHO GHE) }^{9}\end{array}$ & $\begin{array}{c}\text { Reported or } \\
\text { estimated } \\
\text { Mortality of } \\
\text { Mesothelioma } \\
\text { (WHO GCO) }{ }^{10}\end{array}$ \\
\hline 73 & Haiti & LI & No-Ban & C & Yes & No & No & Yes & Yes & Yes \\
\hline 74 & Honduras & LMI & Ban & $\mathrm{C}$ & Yes & Yes & No & Yes & Yes & Yes \\
\hline 75 & Hong Kong ${ }^{1}$ & HI & No-Ban & B & Yes & Yes & Yes & No & No & No \\
\hline 76 & Hungary & $\mathrm{HI}$ & Ban & B & Yes & Yes & Yes & Yes & Yes & Yes \\
\hline 77 & Iceland & $\mathrm{HI}$ & Ban & B & Yes & Yes & Yes & Yes & Yes & Yes \\
\hline 78 & India & LMI & No-Ban & A & Yes & Yes & No & Yes & Yes & Yes \\
\hline 79 & Indonesia & UMI & No-Ban & A & Yes & Yes & No & Yes & Yes & Yes \\
\hline 80 & Iran & UMI & No-Ban & B & Yes & Yes & Yes & Yes & Yes & Yes \\
\hline 81 & Iraq & UMI & Ban & B & Yes & No & Yes & Yes & Yes & Yes \\
\hline 82 & Ireland & $\mathrm{HI}$ & Ban & B & Yes & Yes & Yes & Yes & Yes & Yes \\
\hline 83 & Israel & $\mathrm{HI}$ & Ban & B & Yes & Yes & Yes & Yes & Yes & Yes \\
\hline 84 & Italy & $\mathrm{HI}$ & Ban & B & Yes & Yes & Yes & Yes & Yes & Yes \\
\hline 85 & Jamaica & UMI & No-Ban & B & Yes & Yes & Yes & Yes & Yes & Yes \\
\hline 86 & Japan & $\mathrm{HI}$ & Ban & A & Yes & Yes & Yes & Yes & Yes & Yes \\
\hline 87 & Jordan & UMI & Ban & $\mathrm{B}$ & Yes & Yes & Yes & Yes & Yes & Yes \\
\hline 88 & Kazakhstan & UMI & No-Ban & B & Yes & Yes & Yes & Yes & Yes & Yes \\
\hline 89 & Kenya & LMI & No-Ban & B & Yes & Yes & No & Yes & Yes & Yes \\
\hline 90 & Kiribati & LMI & No-Ban & B & No & Yes & No & Yes & Yes & No \\
\hline 91 & Kuwait & $\mathrm{HI}$ & Ban & C & Yes & Yes & Yes & Yes & Yes & Yes \\
\hline 92 & Kyrgyzstan & LMI & No-Ban & $\mathrm{D}$ & Yes & Yes & Yes & Yes & Yes & Yes \\
\hline 93 & Laos & LMI & No-Ban & A & Yes & Yes & No & Yes & Yes & Yes \\
\hline 94 & Latvia & $\mathrm{HI}$ & Ban & B & Yes & Yes & Yes & Yes & Yes & Yes \\
\hline 95 & Lebanon & UMI & No-Ban & B & Yes & Yes & No & Yes & Yes & Yes \\
\hline 96 & Lesotho & LMI & No-Ban & B & No & Yes & No & Yes & Yes & Yes \\
\hline 97 & Liberia & LI & No-Ban & B & Yes & No & No & Yes & Yes & Yes \\
\hline 98 & Libya & UMI & No-Ban & B & Yes & Yes & No & Yes & Yes & Yes \\
\hline 99 & Liechtenstein & $\mathrm{HI}$ & Ban & B & No & No & No & No & No & No \\
\hline 100 & Lithuania & $\mathrm{HI}$ & Ban & B & Yes & Yes & Yes & Yes & Yes & Yes \\
\hline 101 & Luxembourg & $\mathrm{HI}$ & Ban & $\mathrm{C}$ & Yes & Yes & Yes & Yes & Yes & Yes \\
\hline 102 & Madagascar & LI & No-Ban & $\mathrm{C}$ & Yes & Yes & No & Yes & Yes & Yes \\
\hline 103 & Malawi & LI & No-Ban & $\mathrm{C}$ & Yes & Yes & No & Yes & Yes & No \\
\hline 104 & Malaysia & UMI & No-Ban & B & Yes & Yes & No & Yes & Yes & Yes \\
\hline 105 & Maldives & UMI & No-Ban & $\mathrm{C}$ & Yes & Yes & Yes & Yes & Yes & No \\
\hline 106 & Mali & LI & No-Ban & $\mathrm{D}$ & Yes & Yes & No & Yes & Yes & Yes \\
\hline 107 & Malta & $\mathrm{HI}$ & Ban & B & Yes & Yes & Yes & Yes & Yes & Yes \\
\hline 108 & Marshall Islands & UMI & No-Ban & $\mathrm{B}$ & No & No & No & Yes & No & No \\
\hline 109 & Mauritania & LMI & No-Ban & $\mathrm{D}$ & No & Yes & No & Yes & Yes & No \\
\hline
\end{tabular}


Table A2. Cont.

\begin{tabular}{|c|c|c|c|c|c|c|c|c|c|c|}
\hline & \multirow[b]{2}{*}{ Countries ${ }^{1}$} & \multirow[b]{2}{*}{$\begin{array}{c}\text { World Bank } \\
\text { Income Group }\end{array}$} & \multirow[b]{2}{*}{$\begin{array}{l}\text { Asbestos Ban } \\
\text { Status }^{3}\end{array}$} & \multirow[b]{2}{*}{$\begin{array}{l}\text { NAP Country } \\
\text { Category }{ }^{4}\end{array}$} & \multicolumn{2}{|c|}{ Asbestos Data } & \multicolumn{4}{|c|}{ Disease Data } \\
\hline & & & & & $\begin{array}{c}\text { Consumption } \\
\text { of Raw } \\
\text { Asbestos } \\
\text { (USGS) }^{5}\end{array}$ & $\begin{array}{l}\text { Asbestos- } \\
\text { Containing } \\
\text { Material (UN } \\
\text { Comtrade) }^{6}\end{array}$ & $\begin{array}{c}\text { Reported } \\
\text { Mortality of } \\
\text { Mesothelioma } \\
\text { or Asbestosis } \\
\text { (WHO MDB) }{ }^{7}\end{array}$ & $\begin{array}{l}\text { Estimated } \\
\text { Incidence of } \\
\text { Mesothelioma } \\
\text { (GBD) }{ }^{8}\end{array}$ & $\begin{array}{c}\text { Estimated } \\
\text { Mortality of } \\
\text { Mesothelioma } \\
\text { (WHO GHE) }^{9}\end{array}$ & 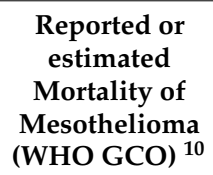 \\
\hline 110 & Mauritius & $\mathrm{HI}$ & Ban & B & Yes & Yes & Yes & Yes & No & No \\
\hline 111 & Mexico & UMI & No-Ban & B & Yes & Yes & Yes & Yes & Yes & Yes \\
\hline 112 & Micronesia & LMI & No-Ban & B & No & Yes & No & Yes & Yes & No \\
\hline 113 & Moldova & LMI & No-Ban & $\mathrm{C}$ & Yes & Yes & Yes & Yes & Yes & Yes \\
\hline 115 & Mongolia & LMI & No-Ban & A & Yes & Yes & Yes & Yes & Yes & Yes \\
\hline 116 & Montenegro & UMI & No-Ban & $\mathrm{C}$ & Yes & Yes & Yes & Yes & Yes & No \\
\hline 117 & Morocco & LMI & No-Ban & C & Yes & Yes & Yes & Yes & Yes & Yes \\
\hline 118 & Mozambique & LI & Ban & B & Yes & Yes & No & Yes & Yes & Yes \\
\hline 119 & Myanmar & LMI & No-Ban & $\mathrm{D}$ & Yes & Yes & No & Yes & Yes & Yes \\
\hline 120 & Namibia & UMI & No-Ban & $\mathrm{C}$ & Yes & Yes & No & Yes & Yes & Yes \\
\hline 121 & Nauru & $\mathrm{HI}$ & No-Ban & B & No & No & No & No & No & No \\
\hline 122 & Nepal & LMI & No-Ban & A & Yes & Yes & No & Yes & Yes & Yes \\
\hline 123 & Netherlands & $\mathrm{HI}$ & Ban & $\mathrm{B}$ & Yes & Yes & Yes & Yes & Yes & Yes \\
\hline 124 & New Zealand & $\mathrm{HI}$ & Ban & B & Yes & Yes & Yes & Yes & Yes & Yes \\
\hline 125 & Nicaragua & LMI & No-Ban & $\mathrm{D}$ & Yes & Yes & Yes & Yes & Yes & Yes \\
\hline 127 & Nigeria & LMI & No-Ban & $\mathrm{B}$ & Yes & Yes & No & Yes & Yes & Yes \\
\hline 128 & North Korea & LI & No-Ban & $\mathrm{D}$ & Yes & No & No & Yes & Yes & Yes \\
\hline 129 & North Macedonia & UMI & Ban & A & Yes & Yes & Yes & Yes & Yes & No \\
\hline 130 & Norway & $\mathrm{HI}$ & Ban & $\mathrm{B}$ & Yes & Yes & Yes & Yes & Yes & Yes \\
\hline 131 & Oman & $\mathrm{HI}$ & Ban & B & Yes & Yes & Yes & Yes & Yes & Yes \\
\hline 132 & Pakistan & LMI & No-Ban & B & Yes & Yes & No & Yes & Yes & Yes \\
\hline 133 & Palau & $\mathrm{HI}$ & No-Ban & B & No & Yes & No & No & No & No \\
\hline 134 & Panama & $\mathrm{HI}$ & No-Ban & $\mathrm{C}$ & Yes & Yes & Yes & Yes & Yes & Yes \\
\hline 135 & Papua New Guinea & LMI & No-Ban & $\mathrm{C}$ & No & Yes & No & Yes & Yes & Yes \\
\hline 136 & Paraguay & UMI & No-Ban & $\mathrm{C}$ & Yes & Yes & Yes & Yes & Yes & No \\
\hline 137 & Peru & UMI & No-Ban & B & Yes & Yes & Yes & Yes & Yes & Yes \\
\hline 138 & Philippines & LMI & No-Ban & $\mathrm{A}$ & Yes & Yes & Yes & Yes & Yes & Yes \\
\hline 139 & Poland & $\mathrm{HI}$ & Ban & B & Yes & Yes & Yes & Yes & Yes & Yes \\
\hline 140 & Portugal & $\mathrm{HI}$ & Ban & B & Yes & Yes & Yes & Yes & Yes & Yes \\
\hline 141 & Qatar & $\mathrm{HI}$ & Ban & B & Yes & Yes & No & Yes & Yes & Yes \\
\hline 142 & Romania & $\mathrm{HI}$ & Ban & B & Yes & Yes & Yes & Yes & Yes & Yes \\
\hline 143 & Russia & UMI & No-Ban & B & Yes & Yes & No & Yes & Yes & Yes \\
\hline 144 & Rwanda & LI & No-Ban & B & Yes & Yes & No & Yes & Yes & Yes \\
\hline 145 & Saint Kitts and Nevis & $\mathrm{HI}$ & No-Ban & $\mathrm{C}$ & No & Yes & No & No & No & No \\
\hline
\end{tabular}


Table A2. Cont.

\begin{tabular}{|c|c|c|c|c|c|c|c|c|c|c|}
\hline & \multirow[b]{2}{*}{ Countries $^{1}$} & \multirow[b]{2}{*}{$\begin{array}{c}\text { World Bank } \\
\text { Income Group }\end{array}$} & \multirow[b]{2}{*}{$\begin{array}{c}\text { Asbestos Ban } \\
\text { Status }^{3}\end{array}$} & \multirow[b]{2}{*}{$\begin{array}{l}\text { NAP Country } \\
\text { Category }{ }^{4}\end{array}$} & \multicolumn{2}{|c|}{ Asbestos Data } & \multicolumn{4}{|c|}{ Disease Data } \\
\hline & & & & & $\begin{array}{c}\text { Consumption } \\
\text { of Raw } \\
\text { Asbestos } \\
\text { (USGS) }^{5}\end{array}$ & $\begin{array}{c}\text { Asbestos- } \\
\text { Containing } \\
\text { Material (UN } \\
\text { Comtrade) }^{6}\end{array}$ & $\begin{array}{c}\text { Reported } \\
\text { Mortality of } \\
\text { Mesothelioma } \\
\text { or Asbestosis } \\
\text { (WHO MDB) }^{7}\end{array}$ & $\begin{array}{l}\text { Estimated } \\
\text { Incidence of } \\
\text { Mesothelioma } \\
\text { (GBD) }{ }^{8}\end{array}$ & $\begin{array}{c}\text { Estimated } \\
\text { Mortality of } \\
\text { Mesothelioma } \\
\text { (WHO GHE) }^{9}\end{array}$ & $\begin{array}{c}\text { Reported or } \\
\text { estimated } \\
\text { Mortality of } \\
\text { Mesothelioma } \\
\text { (WHO GCO) }{ }^{10}\end{array}$ \\
\hline 146 & Saint Lucia & UMI & No-Ban & $\mathrm{C}$ & No & Yes & Yes & Yes & Yes & No \\
\hline 147 & Saint Vincent and Grenadines & UMI & No-Ban & $\mathrm{D}$ & Yes & Yes & No & Yes & No & No \\
\hline 148 & Samoa & UMI & No-Ban & $\mathrm{B}$ & Yes & Yes & No & Yes & Yes & No \\
\hline 149 & San Marino & $\mathrm{HI}$ & No-Ban & B & No & Yes & No & No & No & No \\
\hline 151 & Saudi Arabia & $\mathrm{HI}$ & Ban & B & Yes & Yes & Yes & Yes & Yes & Yes \\
\hline 152 & Senegal & LMI & No-Ban & $\mathrm{C}$ & Yes & Yes & No & Yes & Yes & Yes \\
\hline 153 & Serbia & UMI & Ban & B & Yes & Yes & Yes & Yes & Yes & Yes \\
\hline 154 & Seychelles & $\mathrm{HI}$ & Ban & $\mathrm{C}$ & Yes & Yes & No & Yes & Yes & No \\
\hline 155 & Sierra Leone & LI & No-Ban & $\mathrm{D}$ & Yes & Yes & No & Yes & Yes & No \\
\hline 156 & Singapore & $\mathrm{HI}$ & No-Ban & B & Yes & Yes & Yes & Yes & Yes & Yes \\
\hline 157 & Slovakia & $\mathrm{HI}$ & Ban & B & Yes & Yes & Yes & Yes & Yes & Yes \\
\hline 158 & Slovenia & HI & Ban & B & Yes & Yes & Yes & Yes & Yes & Yes \\
\hline 159 & Solomon Islands & LMI & No-Ban & B & No & Yes & No & Yes & Yes & No \\
\hline 160 & Somalia & LI & No-Ban & $\mathrm{D}$ & No & No & No & Yes & Yes & Yes \\
\hline 163 & South Sudan & LI & No-Ban & B & No & Yes & No & Yes & Yes & Yes \\
\hline 164 & Spain & $\mathrm{HI}$ & Ban & B & Yes & Yes & Yes & Yes & Yes & Yes \\
\hline 165 & Sri Lanka & LMI & No-Ban & B & Yes & Yes & Yes & Yes & Yes & Yes \\
\hline 166 & Sudan & LI & No-Ban & $\mathrm{C}$ & Yes & Yes & No & Yes & Yes & Yes \\
\hline 167 & Suriname & UMI & No-Ban & $\mathrm{D}$ & Yes & Yes & Yes & Yes & Yes & No \\
\hline 168 & Sweden & $\mathrm{HI}$ & Ban & B & Yes & Yes & Yes & Yes & Yes & Yes \\
\hline 169 & Switzerland & $\mathrm{HI}$ & Ban & B & Yes & Yes & Yes & Yes & Yes & Yes \\
\hline 170 & Syria & LI & No-Ban & $\mathrm{C}$ & Yes & Yes & No & Yes & Yes & Yes \\
\hline 171 & Taiwan ${ }^{1}$ & $\mathrm{HI}$ & Ban & B & Yes & No & No & Yes & No & No \\
\hline 172 & Tajikistan & LI & No-Ban & B & Yes & Yes & No & Yes & Yes & No \\
\hline 173 & Tanzania & LMI & No-Ban & $\mathrm{C}$ & Yes & Yes & No & Yes & Yes & No \\
\hline 174 & Thailand & UMI & No-Ban & B & Yes & Yes & Yes & Yes & Yes & Yes \\
\hline 175 & Timor-Leste & LMI & No-Ban & B & No & Yes & No & Yes & Yes & No \\
\hline 176 & Togo & LI & No-Ban & $\mathrm{C}$ & Yes & Yes & No & Yes & Yes & Yes \\
\hline 177 & Tonga & UMI & No-Ban & B & No & Yes & No & Yes & Yes & No \\
\hline 178 & Trinidad and Tobago & $\mathrm{HI}$ & No-Ban & $\mathrm{C}$ & Yes & Yes & Yes & Yes & Yes & No \\
\hline 179 & Tunisia & LMI & No-Ban & $\mathrm{C}$ & Yes & Yes & Yes & Yes & Yes & Yes \\
\hline 180 & Turkey & UMI & Ban & B & Yes & Yes & Yes & Yes & Yes & Yes \\
\hline 181 & Turkmenistan & UMI & No-Ban & $\mathrm{D}$ & Yes & Yes & No & Yes & Yes & Yes \\
\hline 182 & Tuvalu & UMI & No-Ban & B & No & Yes & No & No & No & No \\
\hline
\end{tabular}


Table A2. Cont.

\begin{tabular}{|c|c|c|c|c|c|c|c|c|c|c|}
\hline & \multirow[b]{2}{*}{ Countries $^{1}$} & \multirow[b]{2}{*}{$\begin{array}{c}\text { World Bank } \\
\text { Income Group }\end{array}$} & \multirow[b]{2}{*}{$\begin{array}{l}\text { Asbestos Ban } \\
\text { Status }^{3}\end{array}$} & \multirow[b]{2}{*}{$\begin{array}{l}\text { NAP Country } \\
\text { Category }{ }^{4}\end{array}$} & \multicolumn{2}{|c|}{ Asbestos Data } & \multicolumn{4}{|c|}{ Disease Data } \\
\hline & & & & & $\begin{array}{c}\text { Consumption } \\
\text { of Raw } \\
\text { Asbestos } \\
\text { (USGS) }^{5}\end{array}$ & $\begin{array}{c}\text { Asbestos- } \\
\text { Containing } \\
\text { Material (UN } \\
\text { Comtrade) }^{6}\end{array}$ & $\begin{array}{c}\text { Reported } \\
\text { Mortality of } \\
\text { Mesothelioma } \\
\text { or Asbestosis } \\
\text { (WHO MDB) }{ }^{7}\end{array}$ & $\begin{array}{l}\text { Estimated } \\
\text { Incidence of } \\
\text { Mesothelioma } \\
\text { (GBD) }{ }^{8}\end{array}$ & $\begin{array}{c}\text { Estimated } \\
\text { Mortality of } \\
\text { Mesothelioma } \\
\text { (WHO GHE) }^{9}\end{array}$ & 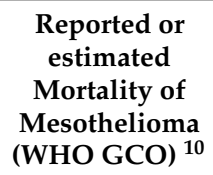 \\
\hline 183 & Uganda & LI & No-Ban & B & Yes & Yes & No & Yes & Yes & Yes \\
\hline 184 & Ukraine & LMI & No-Ban & B & Yes & Yes & No & Yes & Yes & Yes \\
\hline 185 & United Arab Emirates & $\mathrm{HI}$ & No-Ban & B & Yes & Yes & No & Yes & Yes & Yes \\
\hline 186 & United Kingdom & HI & Ban & B & Yes & Yes & Yes & Yes & Yes & Yes \\
\hline 188 & Uruguay & $\mathrm{HI}$ & Ban & $\mathrm{C}$ & Yes & Yes & Yes & Yes & Yes & Yes \\
\hline 189 & Uzbekistan & LMI & No-Ban & $\mathrm{C}$ & Yes & Yes & Yes & Yes & Yes & Yes \\
\hline 190 & Vanuatu & LMI & No-Ban & $\mathrm{B}$ & Yes & Yes & No & Yes & Yes & No \\
\hline 191 & Venezuela & UMI & No-Ban & B & Yes & Yes & Yes & Yes & Yes & Yes \\
\hline 192 & Vietnam & LMI & No-Ban & A & Yes & Yes & No & Yes & Yes & Yes \\
\hline 193 & Yemen & LI & No-Ban & $\mathrm{D}$ & Yes & Yes & No & Yes & Yes & Yes \\
\hline 194 & Zambia & LMI & No-Ban & $\mathrm{C}$ & Yes & Yes & No & Yes & Yes & Yes \\
\hline \multirow[t]{2}{*}{195} & Zimbabwe & LMI & No-Ban & B & Yes & Yes & No & Yes & Yes & Yes \\
\hline & Total (Yes) & & & & 165 & 179 & 96 & 186 & 178 & 134 \\
\hline
\end{tabular}

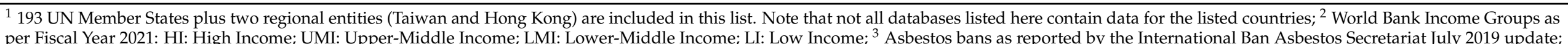

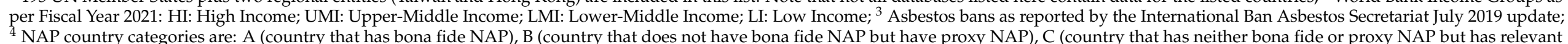

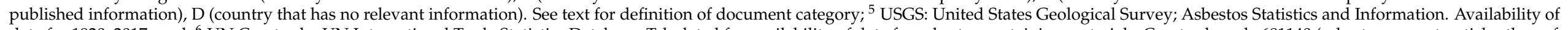

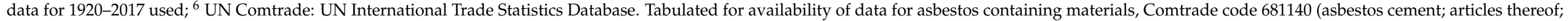

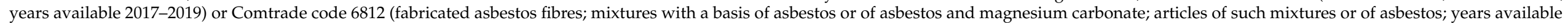

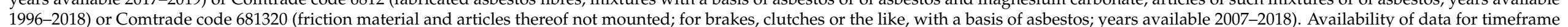

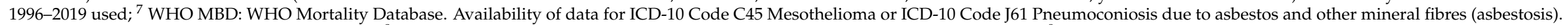

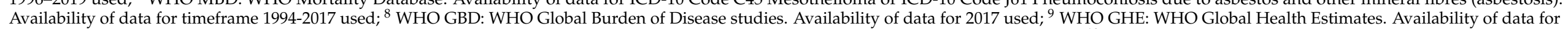

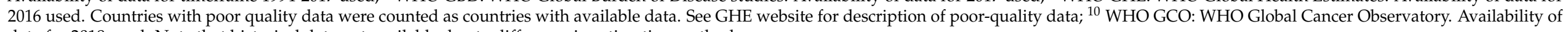
data for 2018 used. Note that historical data not available due to difference in estimation method. 
Table A3. Availability of Data in International and National Sources in Relation to Each NAP Item.

\begin{tabular}{|c|c|c|c|c|c|c|c|c|}
\hline \multirow[b]{3}{*}{ Theme } & \multirow[b]{3}{*}{ Items of National Asbestos Profile } & \multicolumn{6}{|c|}{ International Sources } & \multirow[b]{3}{*}{ National Sources, etc. } \\
\hline & & \multicolumn{2}{|c|}{ Asbestos Data } & \multicolumn{4}{|c|}{ Disease Data } & \\
\hline & & $\begin{array}{l}\text { Consumption of } \\
\text { Raw Asbestos } \\
\text { (USGS }{ }^{1} \text { ) }\end{array}$ & $\begin{array}{l}\text { Asbestos- } \\
\text { Containing } \\
\text { Material (UN } \\
\text { Comtrade }^{2} \text { ) }\end{array}$ & $\begin{array}{c}\text { Reported Mortality } \\
\text { of Mesothelioma or } \\
\text { Asbestosis (WHO } \\
\text { MDB }^{3} \text { ) }\end{array}$ & $\begin{array}{l}\text { Estimated Incidence } \\
\text { of Mesothelioma } \\
\left(G_{B D}^{4}\right)\end{array}$ & $\begin{array}{l}\text { Estimated Mortality } \\
\text { of Mesothelioma } \\
\text { (WHO GHE }{ }^{5} \text { ) }\end{array}$ & $\begin{array}{c}\text { Reported or } \\
\text { estimated Mortality } \\
\text { of Mesothelioma } \\
\left(\text { WHO GCO }{ }^{6}\right)\end{array}$ & \\
\hline Legislation & $\begin{array}{l}\text { I-1. Current regulations on the } \\
\text { different forms of asbestos } \\
\text { I-15. National enforceable occupational } \\
\text { exposure limits for chrysotile asbestos } \\
\text { I-16. The system for inspection and } \\
\text { enforcement of the exposure limits }\end{array}$ & & & & & & & $\begin{array}{l}\text { I-1, I-15, I-16: Existing } \\
\text { government laws and } \\
\text { regulations }\end{array}$ \\
\hline Asbestos & $\begin{array}{l}\text { I-2. Import and consumption of } \\
\text { asbestos per year (total and per major } \\
\text { uses and forms) } \\
\text { I-3. Import of } \\
\text { asbestos-containing materials } \\
\text { I-4. Domestic production of asbestos } \\
\text { (if applicable) } \\
\text { I-5. Domestic production of } \\
\text { asbestos-containing materials }\end{array}$ & $\mathrm{I}-2, \mathrm{I}-4$ & $\mathrm{I}-3, \mathrm{I}-5$ & & & & & $\begin{array}{l}\text { I-2, I-3: National trade } \\
\text { statistics; I-4: National } \\
\text { mining statistics; I-5: } \\
\text { National } \\
\text { manufacturing } \\
\text { statistics }\end{array}$ \\
\hline Diseases & $\begin{array}{l}\text { I-9. Estimate of the burden of diseases } \\
\text { related to asbestos: disability adjusted } \\
\text { life years and deaths attributable to } \\
\text { asbestos exposure } \\
\text { I-10. Prevalence of asbestosis - } \\
\text { national data, a breakdown by } \\
\text { industries if available } \\
\text { I-11. Incidence of lung cancer among } \\
\text { workers exposed to asbestos } \\
\text { I-12. Incidence of mesothelioma } \\
\text { I-17. Estimated economic losses due to } \\
\text { asbestos-related diseases } \\
\text { I-18. Major studies on epidemiology of } \\
\text { asbestos-related diseases in the country }\end{array}$ & & & I-9 (reported deaths) & $\begin{array}{l}\text { I-9, I-10, I-11, I-12 } \\
\text { deaths, DALY) }\end{array}$ & I-9, I-12 (estimated & $\begin{array}{l}\text { I-9, I-12 (reported } \\
\text { a/o estimated } \\
\text { deaths) }\end{array}$ & $\begin{array}{l}\text { I-10: National } \\
\text { compensation } \\
\text { statistics; I-12: } \\
\text { National/Regional } \\
\text { Cancer Registry data; } \\
\text { I-18: PUBMED }\end{array}$ \\
\hline
\end{tabular}


Table A3. Cont.

International Sources

Theme Items of National Asbestos Profile

\section{Asbestos \\ Raw Asbestos}

(USGS ${ }^{1}$ )

Cor

Asbestos-
Containing
Material (UN

Comtrade $^{2}$ )

\section{Reported Mortality \\ of Mesothelioma or}

MDB $^{3}$ )
(W

\section{Disease Data}

\section{Estimated Incidence of Mesotheliom} $\left(\mathrm{GBD}^{4}\right.$ ) Estimated Mortality
of Mesothelioma (WHO GHE ${ }^{5}$ )
Reported or estimated Mortality

of Mesothelioma

I-6. Estimated total number of workers

exposed to asbestos in the country

I-7. Full list of industries where

exposure to asbestos is present in the

country and list of industries with the largest numbers of workers potentially exposed to asbestos

I-8. Industries with high risk of

exposure (where overexposure is

Risk documented as exceeding occupational

Assessment number of workers at high risk

I-13. Estimates on the percentage of

house stock and vehicle fleet

containing asbestos

I-14. Total number of workers eligible

for compensation for asbestos-related

diseases, such as asbestosis, lung

cancer and mesothelioma (per year)

and the numbers of individuals

compensated yearly

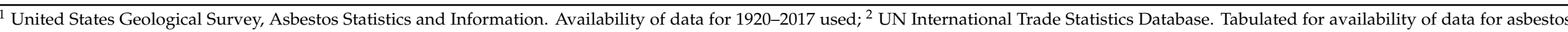

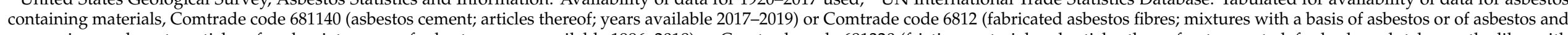

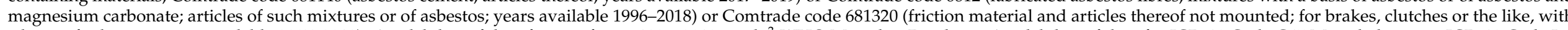

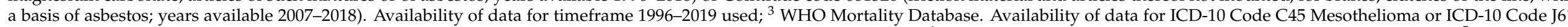

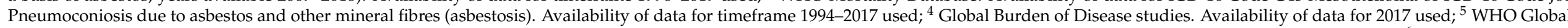

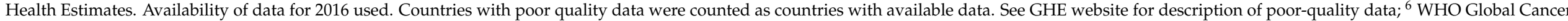

Observatory. Availability of data for 2018 used. Note that historical data not available due to difference in estimation method.

-6, I-8: Industrial

hygiene or

occupational health

data; I-7, I-13: Specific

industry inventory;

-14:

Occupational disease

compensation data. 


\section{References}

1. Institute for Health Metrics and Evaluation, Global Health Data Exchange. Global Burden of Disease Data. 2018. Available online: http:/ / ghdx.healthdata.org/gbd-results-tool (accessed on 15 January 2021).

2. World Health Organization. Elimination of Asbestos-Related Diseases. 2006. Available online: https://www.who.int/ occupational_health/publications/asbestosrelateddiseases.pdf (accessed on 15 January 2021).

3. International Labor Organization and World Health Organization. Outline for the Development of National Programs for Elimination of Asbestos-Related Diseases. 2007. Available online: https:/ /www.who.int/occupational_health/publications / elim_asbestos_doc_en.pdf?ua=1 (accessed on 15 January 2021).

4. International Labor Organization. Thirteenth Session of the Joint ILO/WHO Committee on Occupational Health. 2003. Available online: https://www.ilo.org/wcmsp5/groups/public/---ed_protect/---protrav/---safework/documents/publication/wcms_ 110478.pdf (accessed on 15 January 2021).

5. Kazan-Allen, L. Current Asbestos Bans. 2019. Available online: http://www.ibasecretariat.org/alpha_ban_list.php (accessed on 15 January 2021).

6. Takahashi, K.; Landrigan, P.J.; Ramazzini, C. The global health dimensions of asbestos and asbestos-related diseases. Ann. Glob. Health 2016, 82, 209-213. [CrossRef] [PubMed]

7. Park, E.K.; Takahashi, K.; Hoshuyama, T.; Cheng, T.J.; Delgermaa, V.; Le, G.V.; Sorahan, T. Global magnitude of reported and unreported mesothelioma. Environ. Health Persp. 2011, 119, 514-518. [CrossRef] [PubMed]

8. Lin, R.T.; Takahashi, K.; Karjalainen, A.; Hoshuyama, T.; Wilson, D.; Kameda, T.; Chan, C.C.; Wen, C.P.; Furuya, S.; Higashi, T.; et al. Ecological association between asbestos-related diseases and historical asbestos consumption: An international analysis. Lancet 2007, 369, 844-849. [CrossRef]

9. Delgermaa, V.; Takahashi, K.; Park, E.K.; Le, G.V.; Hara, T.; Sorahan, T. Global mesothelioma deaths reported to the World Health Organization between 1994 and 2008. Bull. World Health Organ. 2011. [CrossRef] [PubMed]

10. Chimed-Ochir, O.; Takahashi, K.; Sorahan, T.; Driscoll, T.; Fitzmaurice, C.; Yoko-o, M.; Sawanyawisuth, K.; Furuya, S.; Tanaka, F.; Horie, S.; et al. Estimation of the global burden of mesothelioma deaths from incomplete national mortality data. Occup. Environ. Med. 2017, 89, 716-724. [CrossRef]

11. GBD 2016 Occupational Carcinogens Collaborators. Global and Regional Burden of Cancer in 2016 Arising from Occupational Exposure to Selected Carcinogens: A Systematic Analysis for the Global Burden of Disease Study 2016. Occup. Environ. Med. 2020, 77, 151-159. [CrossRef] [PubMed]

12. Carbone, M.; Adusumilli, P.S.; Alexander, H.R., Jr.; Baas, P.; Bardelli, F.; Bononi, A.; Bueno, R.; Felley-Bosco, E.; Galateau-Salle, F.; Jablons, D.; et al. Mesothelioma: Scientific clues for prevention, diagnosis, and therapy. Cancer J. Clin. 2019, 69, 402-429. [CrossRef]

13. United Nations. List of Member States. 2019. Available online: https://www.un.org/en/member-states/index.html (accessed on 15 January 2021).

14. World Bank. World Bank Country and Lending Groups. Fiscal Year. 2021. Available online: https://datahelpdesk.worldbank. org/knowledgebase/articles/906519-world-bank-country-and-lending-groups (accessed on 15 January 2021).

15. World Health Organization. List of WHO Member States. 2019. Available online: https://www.who.int/choice/demography/ by_country/en/ (accessed on 15 January 2021).

16. United States Geological Survey. Asbestos Statistics and Information, Minerals Yearbook 1920-2017 (Personal Communication Included). Available online: https:/ / www.usgs.gov/centers/nmic/asbestos-statistics-and-information (accessed on 15 January 2021).

17. United Nations Statistics Division. United Nations International Trade Statistics Database, UN Comtrade. Available online: https: / comtrade.un.org/data/ (accessed on 15 January 2021).

18. World Health Organization. WHO Mortality Database. 2019. Available online: https://www.who.int/data/data-collectiontools / who-mortality-database (accessed on 15 January 2021).

19. World Health Organization. Global Health Estimates 2016: Deaths by Cause, Age, Sex, by Country and by Region, $2000-2016$. Available online: https:/ /www.who.int/healthinfo/global_burden_disease/en/ (accessed on 15 January 2021).

20. World Health Organization. Global Cancer Observatory: Cancer Today. 2018. Available online: https://gco.iarc.fr/today (accessed on 15 January 2021).

21. Wolff, H.; Vehmas, T.; Oksa, P.; Rantanen, J.; Vainio, H. Consensus Report: Asbestos, asbestosis, and cancer, the Helsinki criteria for diagnosis and attribution. Scand. J. Work. Environ. Health 2015, 41, 5-15. [CrossRef] [PubMed]

22. Kameda, T.; Takahashi, K.; Kim, R.; Jiang, Y.; Movahed, M.; Park, E.K.; Rantanen, J. Asbestos: Use, bans and disease burden in Europe. Bull. World Health Organ. 2014, 92, 790-797. [CrossRef]

23. Le, G.V.; Takahashi, K.; Park, E.K.; Delgermaa, V.; Oak, C.; Qureshi, A.M.; Aljunid, S.M. Asbestos use and asbestos-related diseases in Asia: Past, present and future. Respirology 2011, 16, 767-775. [CrossRef]

24. World Health Organization Regional Office for Europe. Parma Declaration on Environment and Health. 2010. Available online: http:/ / www.euro.who.int/_data/assets/pdf_file/0011/78608/E93618.pdf (accessed on 15 January 2021).

25. National Institute for Occupational Safety and Health. Improving Workers' Health across the Globe. 2016. Available online: https://www.cdc.gov/niosh/docs/2016-118/pdfs/success-stories_v01_nr04_n-compressed.pdf (accessed on 15 January 2021) 
26. Asbestos Safety and Eradiation Agency. National Asbestos Profile for Australia. 2017. Available online: https://www. asbestossafety.gov.au/sites/default/files/documents/2017-12/ASEA_National_Asbestos_Profile_interactive_Nov17.pdf (accessed on 11 January 2021).

27. Bangladesh Occupational Safety, Health and Environment Foundation. 2016. National Asbestos Profile of Bangladesh. Per-sonal Communication. 2020.

28. Vangelova, K.; Dimitrova, S.; Dimitrova, I. National Asbestos Profile of Bulgaria. 2015. Available online: https://ncpha. government.bg/files/National\%20Asbestos\%20Profile_Bulgaria_2015-en.pdf (accessed on 11 January 2021).

29. Ministry of Labor and Vocational Training. 2019. Cambodia National Asbestos Profile. Obtained via personal communication: 04 May 2020.

30. Federal Institute for Occupational Health and Safety. National Asbestos Profile for Germany. 2014. Available online: https: / / www.baua.de/EN/Service/Publications/Report/Gd80.pdf?_blob=publicationFile\&v=8 (accessed on 11 January 2021).

31. People's Training \& Research and Centre. India: National Asbestos Profile. 2017. Available online: https://amrc.org.hk/sites/ default/files/NAP\%20India.pdf (accessed on 11 January 2021).

32. Indonesia Ban Asbestos Network. 2017. National Asbestos Profile Indonesia. Personal Communication, 2020.

33. Furuya, S.; Takahashi, K.; Mohaved, M.; Jiang, Y. National Asbestos Profile of Japan. 2013. Available online: https: //www.researchgate.net/publication/237839114_National_Asbestos_Profile_of_Japan_-_Based_on_the_National_Asbestos_ Profile_by_the_ILO_and_the_WHO (accessed on 11 January 2021).

34. Laos Ministry of Industry and Commerce. 2017. National Asbestos Profile of Laos. Personal Communication, 2020.

35. Institute of Occupational Health of the Republic of Macedonia. 2014. National Asbestos Profile for the Republic of Macedonia. Obtained via personal communication: 15 July 2020.

36. Health Sciences University of Mongolia. 2012. National Asbestos Profile of Mongolia. Personal Communication. 2020.

37. Sah, R.C. National Asbestos Profile of Nepal. 2016. Available online: http://anroev.org/aban/wp-content/uploads/2016/10/ National-Abestos-Profile-of-Nepal.pdf (accessed on 11 January 2021).

38. Republic of Philippines, Environmental and Occupational Health Office. National Asbestos Profile Philippines. 2013. Available online: https://www.informea.org/en/national-asbestos-profile-nap-philippines (accessed on 11 January 2021).

39. Pham, V.H.; Tran, T.N.L.; Le, G.V.; Movahed, M.; Jiang, Y.; Pham, N.H.; Ogawa, H.; Takahashi, K. Asbestos and asbestos-related diseases in Vietnam: In reference to the International Labor Organization/World Health Organization National Asbestos Profile. Saf. Health Work 2013, 4, 117-121. [CrossRef] [PubMed] 